\title{
Human Foodways, Metallurgy, and Landscape Modification of Iron Age Central Thailand
}

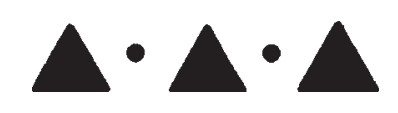

Chin-hsin LiU

\begin{abstract}
The relationship between a population and its immediate natural landscape often shapes the course of social development and cultural practice. The increasing abundance of smelting byproduct in archaeological sites suggests that community-based metallurgical activities, established at least half a millennium earlier, intensified during the Iron Age (ca. 500 B.C.-A.D. 500) in central Thailand. Likely consequences of such a change would include higher demand for firewood, resulting in small-scale forest clearing, with subsequent altered access to wild terrestrial fauna. Tooth enamel from 13 human individuals dated to the Iron Age period of Promtin Tai were sampled for stable carbon isotope analysis to explore how people responded to anthropogenic landscape modification as reflected in the dietary regime. The data revealed that a $\mathrm{C}_{3}$-based dietary pattern was maintained throughout the Promtin Tai occupation. A slight enrichment of $\delta^{13} \mathrm{C}$ values from the Earlier to Later Iron Age may be attributable to increasing consumption of freshwater fauna, domestic fauna, resources collected from or fed on more opened fields, or any combination of these. A wider diversity of food items brought in via trade networks could also have contributed to the flexibility of foodways. The wealth of natural resources in prehistoric central Thailand facilitated the maintenance of a broad-spectrum diet that was also utilized elsewhere in tropical and subtropical Southeast Asia. This study highlights the key role of small sites, often connected by rivers and trade networks, in contributing to the understanding of prehistoric human ecology and cultural complexity in Mainland Southeast Asia. KEYWORDS: bioarchaeology, bone chemistry, stable carbon isotope, tooth enamel apatite, broad-spectrum diet, Mainland Southeast Asia.
\end{abstract}

\section{INTRODUCTION}

THE ASSOCIATION BETWEEN ENVIRONMENTAL AND HUMAN BEHAVIORAL CHANGE, leading to multiscalar cultural change, is well-documented throughout human history. Natural environmental fluctuation and landscape modification (directly or indirectly caused by cultivation, animal husbandry, craft production, population expansion, conflict, etc.) contributed to cultural changes and stimulated a suite of coping mechanisms that are archaeologically visible (Bourke et al. 2007; Chapin et al. 2004; Zeder 2008). A wide variety of analytical approaches have been employed to identify these responses and characterize how people negotiated ever-changing landscapes. These approaches include, but are not limited to, methods derived from zooarchaeology (Deppen and 
Cook 2014; Emery 2008), palaeobotany (Arnold and Martin 2014; Ekblom et al. 2014; Kealhofer and Grave 2008), mathematical modeling (Richerson et al. 2001), and multidisciplinary studies (Atahan et al. 2007; Fraser et al. 2013). Among the materials suitable for the investigation of human-landscape relationships, human skeletal remains often provide the most direct data for gauging past lifeways. Developmental markers and evidence of pathological conditions observable in human skeletal remains can be used to infer the impact of environmental change on human lifeways and social organization (Robbins Schug 2011; Walker 1989; Wright and White 1996). Bone chemistry, stable isotope ratio analysis in particular, is another key approach that is used extensively to assess human dietary regimes and draw inferences about the relationship between landscape change and factors such as subsistence strategy, animal management, and social organization (Coltrain and Leavitt 2002; Reitsema et al. 2013; White et al. 1993; Wright and White 1996).

In central Thailand, specifically on the Lopburi floodplain where the Promtin Tai site is located, phytolith analyses demonstrate that anthropogenic landscape modification such as burning and clearing can be traced back to at least 5000 B.C. (Kealhofer 1997). ${ }^{1}$ Increasing landscape disruption ensued as an agroeconomy developed and the population size grew (Cremaschi et al. 1992; Kealhofer 1997, 2002). This region is also known for having a long history of community-based metallurgy beginning in the second millennium B.C. and intensifying well into the middle of the first millennium A.D. (Rispoli et al. 2013). Cremaschi and colleagues' (1992) geomorphological study in the Lopburi area revealed a series of changes, including slope degradation, increased fluvial activity, and higher evapotranspiration rates in soils, attributable to deforestation related to metallurgy during this period. As metallurgical activities intensified over time, increasing fuel requirements for smelting were satisfied by felling more trees.

These human-induced landscape changes, deforestation in particular, likely impacted the habitats of wild fauna and consequently people's access to these animals as food sources. Based on the faunal remains from a cluster of the late Neolithic to Metal Age sites in the Lopburi region (ca. 7-10 km southeast of Promtin Tai), Mudar and Pigott (2003:154) stated that deer and cattle were the most important wild food resources during the early stages of habitation of the area. Over time, the availability of these terrestrial species would have been negatively impacted by deforestation. Drawing an analogy with similar changes seen in Luzon in the Philippines, Mudar (1985) argued that deer and cattle would have retreated from cleared forests, forcing people to replace the non-domestic portion of their diet with other resources. In Lopburi, people would have responded to the decreasing diversity and accessibility of wild terrestrial animals by incorporating more freshwater species such as fish, turtle, and mollusks into their diet (Mudar and Pigott 2003).

The study reported in this article employs data derived from stable isotope ratio analysis on human tooth enamel recovered from the Iron Age (ca. 500 B.C.-A.D. 500) central Thai site known as Promtin Tai. It aims to test the hypothesis that landscape modification due to intensification of metallurgy over time would have impacted people's diet; specifically, their consumption of freshwater resources would have increased to mitigate the decreasing availability of wild terrestrial fauna. Scenarios that could have led to similar isotopic results are also explored. What people did to manage the impact of landscape change and sustain an adequate diet over time is the main focus of this study. 


\section{CENTRAL THAILAND}

Central Thailand is bordered by modern day Myanmar to the west, the Phetchabun Ridge to the northeast (i.e., the Khorat Plateau), and the Gulf of Thailand to the south. Central Thailand itself encompasses a vast region with varied geological forms ranging from highlands to the riverine central plain of the Chao Phraya River drainage and the undulating terrain of the $\mathrm{Pa}$ Sak River drainage. The interaction between these landforms and the annual monsoon often results in uneven distribution of precipitation in time and space, creating ecological pockets that harbor fauna and flora of tremendous diversity (Higham and Thosarat 1998). Such landscape complexity has been considered instrumental in the development of cultural and population diversity in Thailand (White 2011).

Rice is currently the predominant cultigen in the central plain where Promtin Tai is situated; it was also an important plant resource for people in prehistory (Hanson and d'Alpoim Guedes 2017; Higham 2002). While still part of the tropics, the inland central plain is more arid than the coast and has a longer dry season and flood-inducing rainy season (Higham 2002). It may be possible for the rain or floodwater to sustain one round of wet or "floating" rice agriculture annually. However, the long and often unpredictable drought renders year-round wet rice agriculture unsustainable without irrigation or a water management regime (Higham 2002). Most prehistoric sites in Thailand (and Mainland Southeast Asia in general) are located near waterways, including rivers, creeks, and springs, which have been the main arteries for transportation and subsequent cultural transmissions for a long time, in addition to being sources of irrigation and aquatic foods (Higham and Thosarat 1998, 2012). Promtin Tai is no exception. Thus, in addition to rice and terrestrial fauna, freshwater fauna and flora were also possible food sources available to the prehistoric people inhabiting the central plain.

Among other features, prehistoric central Thailand is particularly noteworthy for housing one of the two major copper mine sources in Thailand. The mine is located in the Khao Wong Prachan Valley, approximately 10-15 km southeast of Promtin Tai. This mining belt also produces iron ore and has been exploited since prehistoric times (Natapintu 1988; Pigott et al. 1997; see Pryce 2009 for a detailed review). The easy access to copper, iron, and other metal ore sources, forests for fuel, and clay for on-site pottery production made central Thailand a hub of metal-working. Ingots, a product of ore smelting used for casting metal objects, were likely traded in extensive exchange networks (see below).

The transmission, development, distribution, and implications of metallurgy in central Thailand are particularly important issues when reconstructing the prehistory of Mainland Southeast Asia (e.g., Higham and Thosarat 1998, 2012; O'Reilly 2001, 2003; Pryce 2009; Rispoli et al. 2013; White and Hamilton 2009; White and Pigott 1996). Metal-working using copper and bronze alloys took place as early as the Bronze Age (ca. 1000-500 B.c.) (Higham and Thosarat 2012). Entering the Iron Age, the refinement and continuous development of metallurgical techniques, combined with social complexity development and (inter)regional interaction, facilitated the expansion of settlements, population growth, and intensification of cultural transmissions (Eyre 2006; Higham and Thosarat 2012). According to Higham and Thosarat (2012), compared to copper, iron ore is much more readily available in central Thailand. While iron working requires higher smelting temperature, repetitive 
hammering to eliminate impurities, and mixing with charcoal to increase tensile strength, iron objects can be forged directly into desired shapes, unlike bronze objects that needed to be casted in molds. The availability of iron ore and manufacture flexibility contributed to increased typological variation and quantity of iron objects. The diverse array of iron tools with multiple functions, mostly utilitarian in nature, provided superb opportunities for the intensification of agriculture, animal domestication, and possibly warfare during the Iron Age (Higham 2002). Thus, the adoption of iron working may have stimulated population expansion, settlement pattern changes (larger and more concentrated sites), and modification of land use patterns (Eyre 2006).

Keeping in mind that there were wide geographic and cultural variations, many Iron Age sites in northeast and central Thailand can be characterized as having one or multiple moats encircling the perimeter of a site (Higham 2004). Scholars have speculated about the function of these moats. To date, water retention and management or defense are the leading explanations for the moats (Higham 1996, 2002, 2004; McGrath and Boyd 2001). Increased control of water may have been necessitated by decreasing rainfall during the Bronze-Iron Age transition in northeast Thailand (Boyd and McGrath 2001; Wohlfarth et al. 2016). In central Thailand, Promtin Tai in particular, Lertcharnrit (2006) believes that moats were present in prehistoric periods, where they functioned as water-retaining facilities for wet-rice agriculture.

The Iron Age saw continuous and intensified development of trade networks that could have connected central Thai communities with people throughout coastal Mainland Southeast Asia, including areas in modern day Cambodia, Vietnam, Myanmar, and India (Carter 2013). Although human skeletons were not preserved, Ban Don Ta Phet (ca. early fourth century B.C.) in western central Thailand displayed a suite of Iron Age funerary features (Glover 1980, 1983). In addition to the heavily Indian-influenced material assemblage, Ban Don Ta Phet yielded metal objects with technological characteristics similar to those found in the Khorat Plateau in northeast Thailand and a nephrite ornament commonly seen in Vietnam and the Philippines (Glover 1990; Higham 2004). More recently, agate and carnelian ornaments from another Iron Age site (Khao Sam Kaeo) in peninsular Thailand further highlight the presence of a cultural and material interaction network between the Indian subcontinent and Mainland Southeast Asia (Bellina and Glover 2004; Glover and Bellina 2011; Indrawooth 2004). Prehistoric central Thai people's engagement in such extensive trade networks eventually led to the transmission of religious beliefs and associated social structures, arts (including metallurgy), and lifeways as the area transitioned into the historical period (Higham and Thosarat 2012).

The technical aspect of metal-working is integral to understanding the ecological impact of metallurgy. Copper ore smelting and iron forging require high temperatures (ca. $1150-1250{ }^{\circ} \mathrm{C}$ for copper smelting and higher for iron) (Higham 2004; Pryce 2009). The tropical monsoon conditions in the Khao Wang Prachan Valley and around Promtin Tai suggest that the local oak-dipterocarp species were possible sources of charcoal (Pigott, pers. comm. cited by Pryce 2009:223). Active metal working during later prehistoric periods in central Thailand resulted in a higher demand for firewood, which intensified the deforestation process (Cremaschi et al. 1992; Mudar and Pigott 2003).

Landscape modifications and changing patterns of land use are key characteristics of Iron Age central Thailand and beyond (Higham 2002). Mudar and Pigott (2003) argue 
that certain species of wild terrestrial fauna inhabiting forested environments would likely have retreated and become more difficult to obtain. In Promtin Tai, skeletal remains of several deer and wild bovine species were present (Lertcharnrit 2014) (see below). Among them, muntjac (Muntiacus sp.) bones are quite abundant. Deer species in general are habitat specialists and are sensitive to habitat changes (Hanley 1996). While some deer may be attracted to forest edges and cleared fields, others tend to remain within dense forests. For example, studies conducted in India and Thailand reveal that the muntjacs are distributed in closed canopy forests and habitually select their bedding locales in forested areas with high canopy cover (Brodie and Brockelman 2009; Ilyas and Khan 2003:522). If this behavioral pattern held true in prehistoric central Thailand, forest clearing would have driven some fauna, muntjacs in particular, deeper into the forests, lowering their accessibility as a human food source. Mudar and Pigott (2003) suggest that humans may have had to replace the non-domestic portion of their protein sources, which earlier came largely from forest-dwelling mammals, with more freshwater fauna.

\section{PROMTIN TAI}

Promtin Tai is situated on an eroded limestone terrace about $10-20 \mathrm{~m}$ above current sea level in Kok Samrong District, Lopburi Province (Fig. 1). It is close to the copper ore source of Khao Wong Prachan Hill, about $12 \mathrm{~km}$ to the southeast of where copper smelting began as early as the second millennium B.C. and persisted well into the first millennium B.C. (Lertcharnrit 2006; Pigott et al. 1997). The original site is believed to be a small semicircular moated town, about $1 \mathrm{~km}^{2}$ in area (Lertcharnrit 2006). It was first explored in the early 1980s; test pits excavated in 1991 and 2004 yielded a few poorly preserved human skeletons dated to the late Bronze Age by artifact association. A preliminary cultural chronology was established based on ceramic and metal artifact typologies; it suggests that occupation may have begun during the late Bronze Age (ca. 700-500 B.C.) and persisted uninterrupted into the early historical period of Dvaravati (A.D. 500-700) (Lertcharnrit 2006). While traces of Bronze Age phases were preserved, Lertcharnrit (2014) notes that Promtin Tai's most intensive occupation occurred during the Iron Age (ca. 500 B.C.-A.D. 500). After a hiatus, the site was reoccupied during the Ayutthaya period (ca. A.D. mid-fourteenth to eighteenth centuries). The lengthy occupation makes Promtin Tai a rarity in central Thailand, as most sites in the region do not span the transition from the Iron Age to the historical period (Lertcharnrit 2006).

Human activity continued from the basal layer into the Iron Age phase, where the majority of the extended supine burials were encountered. The burials were often accompanied by pottery, iron tools, glass beads, bronze ornaments, and in one burial, a bronze bowl (Lertcharnrit 2006). In non-mortuary contexts, stone and clay bracelets, spindle whorls, polished stone adzes, and beads (glass, carnelian, and agate) were common. These mortuary patterns are similar to other Iron Age sites in central Thailand (Lertcharnrit 2006).

A large amount of fragmentary faunal remains were recovered from Promtin Tai, most of which were mixed in with grave fill, though some were clearly deposited as grave goods. Preliminary faunal identification during excavation suggested there were a wide range of terrestrial species accessible to the prehistoric Promtin Tai people, including wild boars, a variety of deer and wild bovid species, rats, dogs, birds, and snakes (Lertcharnrit 2014). Personal observation during the 2007 field season and subsequent field studies suggests that pigs (likely domesticated), chickens, and muntjacs 


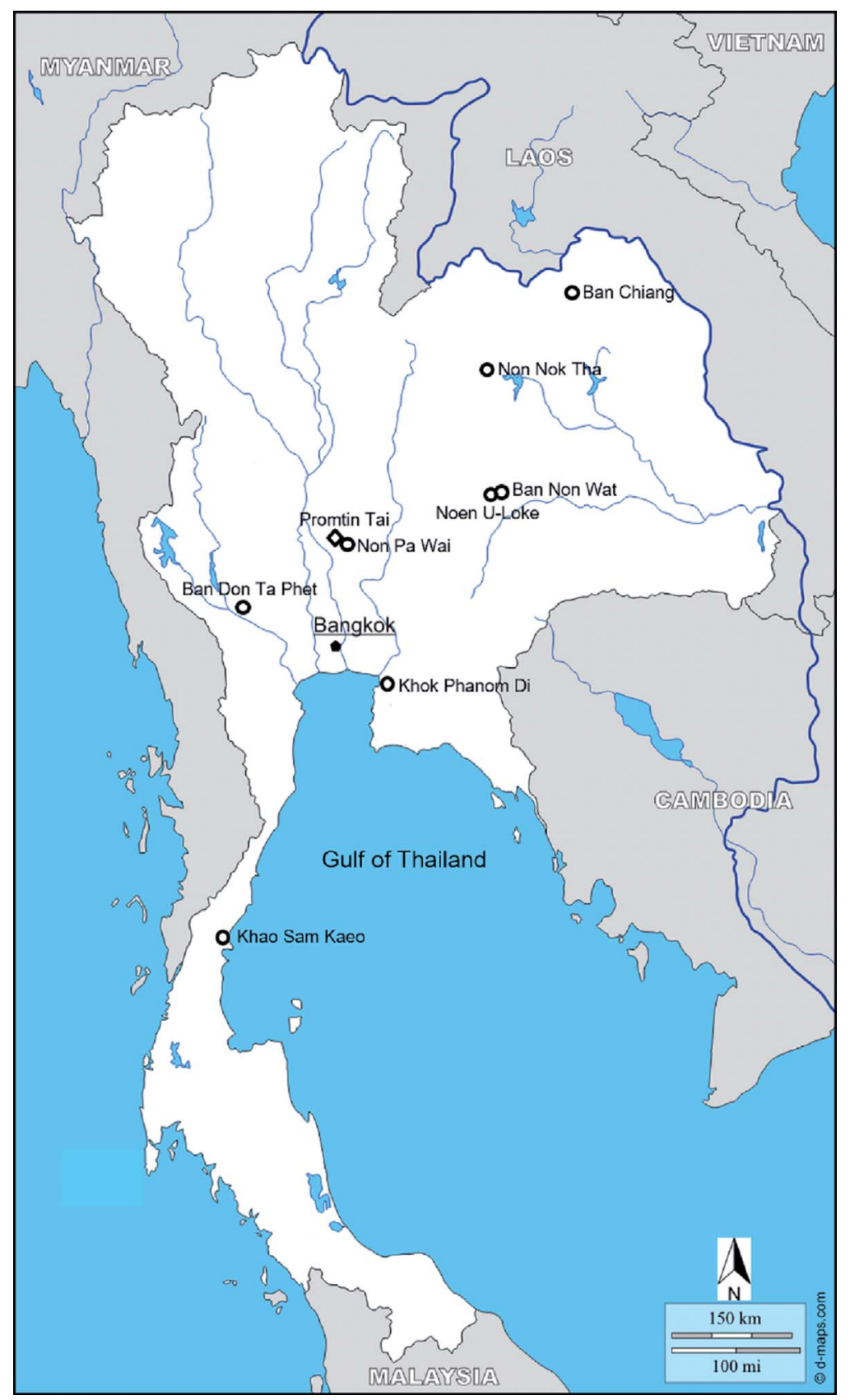

Fig. 1. Map of Thailand showing locations of mentioned sites. Source: Modified from d-maps.com 2007-2017, URL: d-maps.com/carte.php?num_car=14628\&lang=en 
(Muntiacus sp.) are also present in the faunal assemblage. Lertcharnrit (2014) postulates that wild terrestrial fauna were acquired by hunting using wooden bows (not preserved) with clay pellets. Some turtle remains and large quantities of land snails and freshwater bivalves make up the majority of (semi-)aquatic species. Aquatic resources were readily accessible as Promtin Tai was surrounded by creeks, ponds, and most likely rice fields. Unfortunately, detailed faunal analyses such as species density and temporal distribution have not been systematically conducted at Promtin Tai.

Zooarchaeological evidence demonstrates that domestic animals were present in northern (Ban Chiang and Non Nok Tha) (Higham 1975; Higham and Leach 1971), northeast (Ban Non Wat) (Kijngam 2011), and central (Non Pa Wai and Khok Phanom Di) (Higham 2004; Mudar and Pigott 2003) Thailand at least one millennium before the Promtin Tai occupation (see details in Piper 2017). Lertcharnrit (2014) notes that domesticated cattle bones associated with the early historic period were excavated in considerable quantities from Promtin Tai. It is very likely that domestic animals such as pigs and cattle existed and were consumed there during the Iron Age, if not earlier. As for plants, a recent seed analysis of Promtin Tai soil samples by Hanson and d'Alpoim Guedes (2017) reveals that rice was the dominant crop; other seed remains such as millet occur in smaller amounts.

Slag was found ubiquitously in non-burial and burial contexts, the latter mixed with the sediment directly covering the interments. As of the end of the 2004 field season, Lertcharnrit (2006) reports the discovery of a $20 \mathrm{~cm}$ layer of slag embedded in the Iron Age occupation. The site continued to yield large amounts of slag in subsequent excavation seasons (personal observation). In 2011, the current author observed that iron oxide-infused reddish earth was still visible near hillsides where deposits of rich iron ore had been exploited just outside of Promtin Tai village. Stone molds and a few copper ingots were also recovered (Lertcharnrit 2006, 2014). While no sign of burnt earth or fragments of furnace or chimney was discovered in the excavated areas, the abundance of slag and the presence of metal-working related objects suggest the existence of in situ ore smelting at Promtin Tai. However, the disparity between the amount of slag and the rarity of ingots prompted Lertcharnrit $(2006,2014)$ to infer that prehistoric metal-working at Promtin Tai was likely conducted for the purpose of exchange rather than to fulfill domestic needs.

Regardless of the consumers of the ingots and metal products, the proximity to ore sources and the sheer abundance of metallurgical byproducts at Promtin Tai imply a high demand for firewood, which would have been converted into charcoal to fuel various stages of the metal-working process. Over time, demand for firewood may have heightened as iron working increased; evidence for this includes the accumulation of slag, diversity of metal objects associated with burial contexts, and expansion of trade networks.

While the Iron Age occupation at Promtin Tai appeared to be continuous, slight soil changes and ceramic typology variation warrant the classification of burials into Earlier and Later Iron Age periods (Lertcharnrit, pers. comm. 2007). This categorization made the observation of the potential diachronic human dietary behavior change possible. The study of Promtin Tai human skeletons helps characterize the many small but diverse Iron Age sites on central Thailand's undulating terrain. With larger sites existing in neighboring northeast and northern Thailand, the smaller sites in central Thailand contain a wealth of information relevant for reconstructing past human lifeways with respect to landscape changes. 


\section{STABLE ISOTOPE ANALYSIS}

Isotopic signatures of an organism's food and water sources are developed around the time of consumption and incorporated into tissues via digestive and metabolic processes (Ambrose 1993; DeNiro 1987; Hoefs 2009). Accordingly, for the past several decades, stable isotope ratio analysis has been routinely integrated into bioarchaeological studies as a proxy for past diet and human ecology (Ambrose et al. 1997, 2003; Knudson and Torres-Rouff 2009; Turner and Armelagos 2012; Tykot et al. 2009). Similar to bone apatite, enamel apatite is a biogenic carbonate that can be purified from enamel matrix. Unlike bone apatite however, tooth enamel is more resistant to the post-depositional diagenesis that can alter biogenic carbonate; it is thus better suited for gauging past diet from poorly preserved skeletal remains (Lee-Thorp and van der Merwe 1991; Schoeninger et al. 1989; Wang and Cerling 1994). After first being suggested by Krueger and Sullivan (1984), later experimental feeding studies have demonstrated that an individual's total diet (protein, lipids, and carbohydrates) is better characterized by apatite than by bone collagen (Ambrose and Norr 1993; Tieszen and Fagre 1993). Since enamel does not remodel after mineralization is complete, tooth enamel apatite represents a snapshot of the diet from late fetal to early adolescence, depending on the tooth analyzed. The stable isotope ratio of a sample is calculated by comparing it to an isotopically known sample ("standard"). The standard for stable carbon and oxygen isotopes used in this study is NBS-19, a laboratory equivalent of the Pee Dee Belemnite (PDB) (Craig 1957).

Among various chemical elements incorporated in enamel apatite, the carbon stable isotope ratio $\left(\delta^{13} \mathrm{C}\right)$ was used to examine the diet of the Promtin Tai population. Based on differential fractionation of carbon isotopes during $\mathrm{CO}_{2}$ fixation by plants, stable carbon isotopes are often analyzed to distinguish terrestrial plants using $\mathrm{C}_{3}$ versus $\mathrm{C}_{4}$ photosynthetic pathways. $\mathrm{C}_{3}$ plants (trees, herbs, most shrubs, temperate grasses) are more depleted in ${ }^{13} \mathrm{C}$ than $\mathrm{C}_{4}$ plants (arid-adapted grasses, sedges) (Lee-Thorp et al. 1989). Therefore, the $\delta^{13} \mathrm{C}$ values of $\mathrm{C}_{3}$ plants fall between $-35 \%$ and $-20 \%$ (average $-27 \%$ ) whereas $\mathrm{C}_{4}$ plants show a smaller range of $-7 \%$ to -16\% (average -12.5\%) (O'Leary 1981, 1988; Tykot 2006). In Southeast Asia, rice is the major $\mathrm{C}_{3}$ plant utilized by humans, along with tubers, nuts, and most vegetables. The $\mathrm{C}_{4}$ plants exploited in this region may have included millet, sorghum, sugarcane, and Job's tears (Krigbaum 2005).

Upon consumption, the digestive process further fractionates carbon isotopes creating an offset between the ratios in plants consumed and those in the tissues of the consumer. For humans, a pure $\mathrm{C}_{3}$ consumer (i.e., who only eat $\mathrm{C}_{3}$ plants and/or animals that only fed on $\mathrm{C}_{3}$ plants) is expected to have an average $\delta^{13} \mathrm{C}$ value around $-14.5 \%$ from enamel apatite, and a pure $\mathrm{C}_{4}$ consumer would have an average $\delta^{13} \mathrm{C}$ value approaching $-0.5 \%$ (Tykot 2006). Consumption of marine resources would place the consumers at the less negative end of the $\delta^{13} \mathrm{C}$ spectrum, due to these organisms' carbonate source having a $\delta^{13} \mathrm{C}$ value of $0 \%$ o (Katzenberg 2008).

Although prehistoric Southeast Asia's sea level was likely higher, placing the coast closer to most inland sites (Higham and Thosarat 1998), faunal and archaeological evidence suggest little marine influence on Promtin Tai people's diet. Freshwater fauna and flora, on the other hand, likely contributed significantly. These items have highly variable $\delta^{13} \mathrm{C}$ values owing to their isotopically varied carbon sources, so they impact their consumers' $\delta^{13} \mathrm{C}$ in a more unpredictable manner (Katzenberg 2008). 
However, studies on lacustrine ecosystems have found that littoral fish species tend to have heavier $\delta^{13} \mathrm{C}$ than those inhabiting deeper waters, making their consumers' $\delta{ }^{13} \mathrm{C}$ values more positive (Hecky and Hesslein 1995; Katzenberg and Weber 1999).

Oxygen stable isotope ratios $\left(\delta^{18} \mathrm{O}\right)$, also obtained through analysis of tooth enamel apatite, are an environmental marker highly reflective of local meteoric precipitation (Wright and Schwarcz 1998). They are often used to address issues such as water sources and mobility (Bryant et al. 1996; Katzenberg 2008; Schoeninger et al. 2003). Since this study focuses on the dietary aspect of potential human responses to landscape modification, $\delta^{18} \mathrm{O}$ data are reported to anchor the $\delta^{13} \mathrm{C}$ data when interpreting the Promtin Tai palaeodiet and will not be discussed in detail.

\section{MATERIALS AND METHODS}

A total of 35 human burials were discovered at Promtin Tai during field seasons spanning 2007-2012, all of which date to the Iron Age. The age and sex of each individual was assessed following methods in Buikstra and Ubelaker (1994). There are nine males, six females, and 20 individuals with unidentifiable sex. Of those with indeterminate sex, six are younger than 20 years old. Young (21-35 years) and middleaged (36-50 years) adults are primary groups.

When possible, a third molar was sampled for each individual. In cases where no third molar was present or directly accessible, the tooth whose enamel was latest to form was selected. Thus, the data in this study represent isotopic signals incorporated into each individual during different enamel formation times. Due to differential preservation, a total of 13 individuals were sampled for this study, each represented by one tooth free of pathology or anomalies. According to Lertcharnrit's (pers. comm. 2007) division of the burials based on stratigraphy and ceramic typology, nine of the 13 individuals belong to the Earlier period and four belong to the Later period. The provenience and demographic parameters of these samples are listed in Table 1. Unlike faunal bones, faunal dental remains were scarce and fragmentary in Promtin Tai, rendering reliable identification of species difficult. Therefore, no faunal tooth enamel data are reported here.

Enamel apatite was purified following a protocol based on Lee-Thorp (1989) with modifications made to accommodate the samples' antiquity and state of preservation. A small portion of enamel from each tooth was harvested using a Brasseler dental drill with a carbide tip under a binocular microscope lit by microfiber optical light sources. The sectioned enamel was then cleaned of all dentin, discoloration, and microscopically visible debris. The enamel section was ground into fine powder, placed in a $2 \mathrm{ml}$ microcentrifuge tube (samples weighted between 0.2 and $0.5 \mathrm{~g}$ ) with 50 percent sodium hypochlorite solution for $16 \mathrm{~h}$. Each sample was rinsed with distilled water to a neutral $\mathrm{pH}$ before reacting in a $0.1 \mathrm{M}$ acetic acid bath for another $16 \mathrm{~h}$. After being rinsed to a neutral $\mathrm{pH}$, the samples were frozen and lyophilized. Approximately $0.5-0.6 \mathrm{mg}$ of a purified sample was loaded into a Finnigan MAT 251 mass spectrometer at the Department of Geological Sciences, University of Florida to measure the stable isotope ratios for carbon and oxygen. Seventy-one NBS-19 (PDB standard) were run to examine instrument precision. The $\delta^{13} \mathrm{C}$ precision is $\pm 0.02 \%$ o and $\delta^{18} \mathrm{O}$ precision is $\pm 0.06 \%$. 
Table i. Provenience and Stable Isotope Ratio Analysis Results of Promtin Tai Tooth ENAMEL SAMPLES

\begin{tabular}{|c|c|c|c|c|c|c|c|c|c|}
\hline LAB ID & BURIAL & PERIOD $^{a}$ & SEX ${ }^{b}$ & AGE & AGE GROUP $^{c}$ & TоОтн $^{\mathrm{d}}$ & $\delta^{\mathrm{I} 3} \mathrm{C}_{\mathrm{PDB}}$ & $\delta^{18} \mathrm{O}_{\mathrm{PDB}}$ & $\delta^{18} \mathrm{O}_{\text {SMOW }}$ \\
\hline 1090 & B2 & $\mathrm{L}$ & M & $40-50$ & MA & LLM1 & -8.64 & -6.09 & 24.63 \\
\hline 1091 & B5 & $\mathrm{L}$ & $\mathrm{F}$ & $20-25$ & YA & LLM3 & -11.97 & -5.12 & 25.63 \\
\hline 1092 & B6 & $\mathrm{L}$ & UID & $1-2$ & SA & URm1 & -12.32 & -5.45 & 25.29 \\
\hline 1093 & B7 & $\mathrm{E}$ & $\mathrm{F}$ & $25-30$ & YA & LRM3 & -13.14 & -4.76 & 26.00 \\
\hline 1094 & B8 & $\mathrm{E}$ & M & $35-40$ & MA & LRM3 & -11.64 & -5.44 & 25.30 \\
\hline 1096 & B12 & $\mathrm{E}$ & M & $18-22$ & YA & LRM3 & -12.96 & -4.48 & 26.29 \\
\hline 1097 & B13 & $\mathrm{E}$ & UID & $20+$ & A & URM3 & -12.00 & -5.05 & 25.70 \\
\hline 1098 & B16 & $\mathrm{E}$ & $\mathrm{F}$ & $20-22$ & YA & LLM2 & -13.45 & -3.74 & 27.05 \\
\hline 1100 & B18 & $\mathrm{E}$ & UID & $3.5-4.5$ & SA & URM1 & -12.19 & -3.66 & 27.14 \\
\hline 1101 & B19 & $\mathrm{E}$ & UID & $9.5-11$ & SA & URM1 & -12.33 & -3.38 & 27.43 \\
\hline 1102 & $\mathrm{~B} 20$ & $\mathrm{E}$ & $\mathrm{F}$ & $20-25$ & YA & URM2 & -13.47 & -4.12 & 26.66 \\
\hline 1103 & $\mathrm{~B} 23$ & $\mathrm{~L}$ & UID & $3.5-4.5$ & SA & ULM1 & -12.89 & -5.00 & 25.76 \\
\hline 1104 & B24 & $\mathrm{E}$ & M & $37-50$ & MA & ULP3 & -12.59 & -4.69 & 26.08 \\
\hline
\end{tabular}

${ }^{\mathrm{a}}$ E: Early Iron Age; L: Late Iron Age.

${ }^{\mathrm{b}}$ M: male; F: female; UID: sex unidentifiable.

${ }^{\text {c }}$ SA: subadult ( $0-20$ years); YA: young adult (21-35 years); MA: middle adult (36-50 years); A: adult with specific age unidentifiable.

${ }^{\mathrm{d}}$ For an item with all capitalized letters, first letter indicates jaw (U: upper or maxillary; L: lower or mandibular), second indicates side (R: right; L: left), third indicates tooth type (M: molar; P: premolar), fourth indicates position; URm1 = deciduous upper right first molar.

${ }^{\mathrm{e}} \delta^{18} \mathrm{O}_{\mathrm{PDB}}$ is converted to $\delta^{18} \mathrm{O}_{\mathrm{SMOW}}$ for comparison purposes (Coplen et al. 1983).

\section{RESULTS AND DISCUSSION}

The $\delta^{13} \mathrm{C}$ and $\delta^{18} \mathrm{O}$ values of the Promtin Tai human tooth enamel samples are presented in Table 1 and summarized in Table 2. Fig. 2 displays the overall distribution of these isotope values. Burial 2 is an apparent outlier that falls beyond the data cluster on both the carbon and oxygen axes. Reviewing its provenience, Burial 2 was the most recent burial atop a segment of sterile sediment separating it from the rest of the burials. It is considered a temporal outlier that could have been interred later than its Iron Age counterparts. Therefore, Burial 2 is removed from statistical analysis and interpretation.

When Burial 2 is excluded, distribution of the $\delta^{13} \mathrm{C}$ data is somewhat wider than that of the $\delta^{18} \mathrm{O}$. Since a pure $\mathrm{C}_{3}$ dietary regime would result in a mean $\delta^{13} \mathrm{C}$ value of $-14.5 \%$ o (Tykot 2006, see above), the mean $\delta^{13} \mathrm{C}$ of $-12.58 \%$ for Promtin Tai tooth enamel apatite suggests a $\mathrm{C}_{3}$-reliant total diet, including consumption of plants and animals that fed on $\mathrm{C}_{3}$-based foods. The existence and possible consumption of rice may have occurred as early as the Neolithic period at the coastal central Thai site of Khok Phanom Di (Higham and Thosarat 1994). For inland central Thailand, Weber and colleagues' (2010) palaeobotanical study documents that rice grains entered the Khao Wong Prachan Valley context at around the first millennium B.C. At Promtin Tai, the amount of annual rainfall (ca. $871-1317 \mathrm{~mm}$ ), its low altitude, moat construction, and sticky-clay soils make it well suited for rain-filled rice cultivation (Lertcharnrit 2006, 2014). The presence of iron tools (Lertcharnrit 2006, 2014) and the fact that rice made up nearly all of the crop seeds recovered from soil samples (Hanson and d'Alpoim Guedes 2017) strongly suggest on-site rice cultivation and heavy dietary 
Table 2. Summary of Stable Isotopic Values (\%) of Promtin Tai Tooth Enamel Apatite SAMPLES $^{\mathrm{a}}$

\begin{tabular}{|c|c|c|c|c|c|c|c|}
\hline & \multicolumn{2}{|c|}{ SEX } & \multirow[b]{2}{*}{ ALL ADULTS } & \multirow[b]{2}{*}{ SUBADULT } & \multicolumn{2}{|c|}{ PERIOD } & \multirow[b]{2}{*}{ TOTAL } \\
\hline & MALE & FEMALE & & & EARLIER & LATER & \\
\hline \multicolumn{8}{|l|}{$\delta^{13} \mathrm{C}_{\mathrm{PDB}}$} \\
\hline$N^{\mathrm{b}}$ & 3 & 4 & 8 & 4 & 9 & 3 & 12 \\
\hline Mean & -12.40 & -13.01 & -12.65 & -12.43 & -12.64 & -12.39 & -12.58 \\
\hline $\mathrm{SD}^{\mathrm{c}}$ & 0.68 & 0.71 & 0.71 & 0.31 & 0.65 & 0.46 & 0.60 \\
\hline Minimum & -12.96 & -13.47 & -13.47 & -12.89 & -13.47 & -12.89 & -13.47 \\
\hline Maximum & -11.64 & -11.97 & -11.97 & -12.19 & -11.64 & -11.97 & -11.64 \\
\hline \multicolumn{8}{|l|}{$\delta^{18} \mathrm{O}_{\mathrm{PDB}}$} \\
\hline$N$ & 3 & 4 & 8 & 4 & 9 & 3 & 12 \\
\hline Mean & -4.87 & -4.44 & -4.68 & -4.37 & -4.37 & -5.19 & -4.57 \\
\hline SD & 0.50 & 0.62 & 0.55 & 1.0 & 0.69 & 0.23 & 0.70 \\
\hline Minimum & -5.44 & -5.12 & -5.44 & -5.45 & -5.44 & -5.45 & -5.45 \\
\hline Maximum & -4.48 & -3.74 & -3.74 & -3.38 & -3.38 & -5.00 & -3.38 \\
\hline
\end{tabular}

${ }^{\mathrm{a}} \mathrm{B} 2$ excluded.

${ }^{\mathrm{b}} N$ : number of samples (individuals).

${ }^{c} \mathrm{SD}$ : standard deviation.

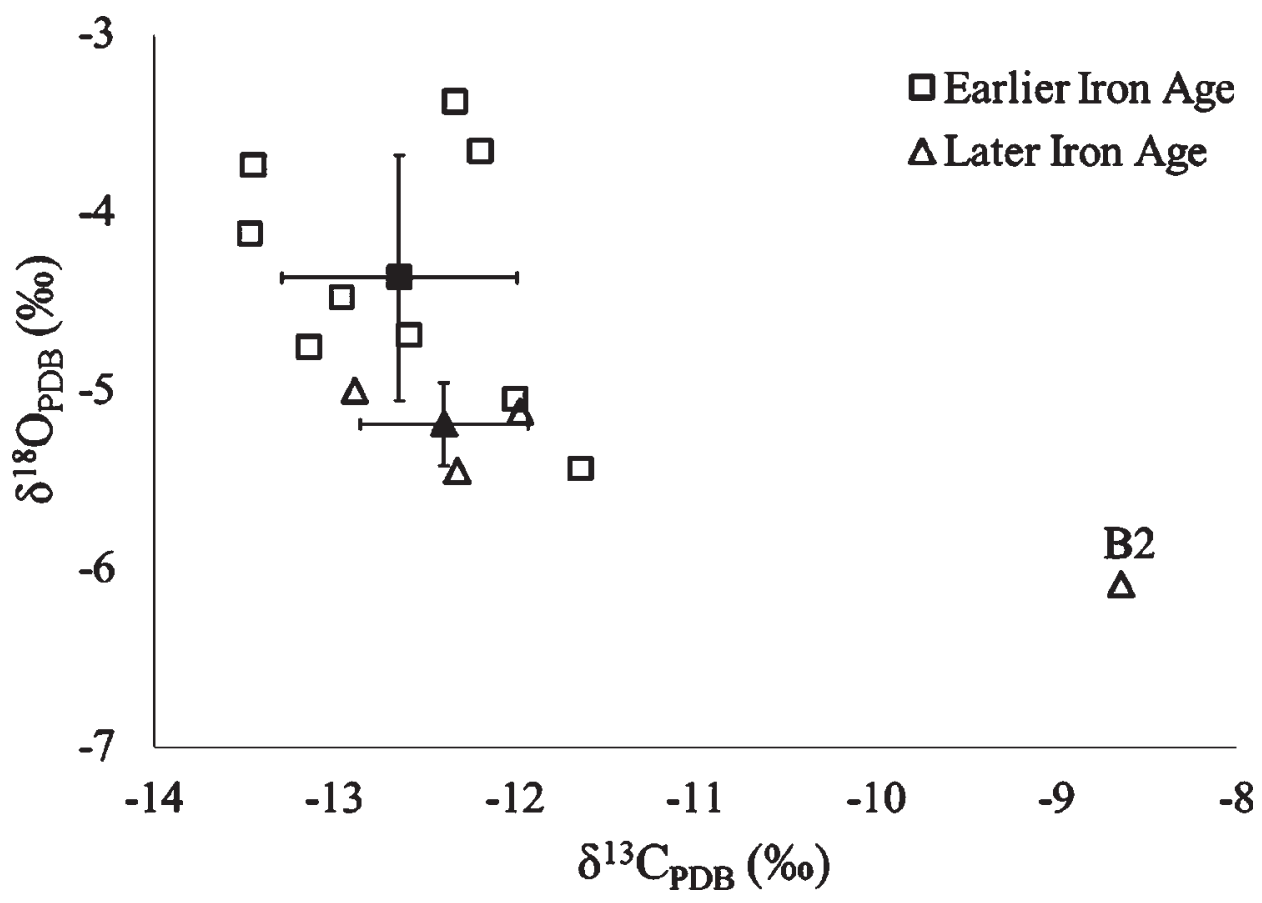

Fig. 2. Stable carbon and oxygen isotope ratios of Promtin Tai tooth enamel apatite. Filled markers indicate means for each period; error bars indicate one standard deviation; outlier B2 excluded from analysis. 
reliance. In addition to rice, other $\mathrm{C}_{3}$ plants such as tubers and various vegetables (e.g., Vigna radiata or mung bean) could also have been incorporated into the Promtin Tai human diet (Hanson and d'Alpoim Guedes 2017).

Foxtail millet ( $\mathrm{C}_{4}$ plant) was available in the Khao Wang Prachan Valley as early as the third millennium B.C. (Weber et al. 2010). With the very small amount of millet found in Promtin Tai soil samples (Hanson and d'Alpoim Guedes 2017), it is likely that millet may have been incorporated into people's diet, but only as a dietary supplement rather than a staple.

Given the landscape and abundance of freshwater bivalves, fish, and land snails, it is certain that Promtin Tai people consumed freshwater resources. Freshwater fauna generally display a wide variation of $\delta^{13} \mathrm{C}$ values due to their consumption of freshwater plants that have more variable carbon sources than terrestrial plants (Katzenberg 2008; Zohary et al. 1994). A higher trophic level, most often induced by the consumption of animal proteins, also contributes to the slight elevation of a consumer's $\delta^{13} \mathrm{C}$ value (ca. 1\%) (Schoeninger 1985). At Promtin Tai, the departure of the population's $\delta^{13} \mathrm{C}$ values from a pure $\mathrm{C}_{3}$ dietary regime is attributable to the combined effect of a small amount of $\mathrm{C}_{4}$ food consumption and the trophic level effect brought about by consuming freshwater resources and terrestrial animals.

Collectively, the Iron Age Promtin Tai diet is best characterized as a broad-spectrum dietary regime, where $\mathrm{C}_{3}$-based plants, freshwater fauna, and terrestrial fauna were heavily utilized, with possible supplementation with $\mathrm{C}_{4}$ resources. Promtin Tai's mean $\delta^{13} \mathrm{C}(-12.58 \%$ o) is on par with those of other ricebased communities in Southeast Asia. King and colleagues (2013) observe that rice agriculturists in prehistoric Mainland Southeast Asia (such as at Ban Chang and Noen U-Loke) who subsisted on a single $C_{3}$ plant have apatite $\delta^{13} \mathrm{C}$ values around $-13 \%$. Most remarkably, Promtin Tai's mean $\delta^{13} \mathrm{C}$ is nearly identical with that of Ban Non Wat during the latter's Iron Age I phase (ca. 420-100 B.C., date follows Higham and Higham 2009) in northeast Thailand (King et al. 2013). In Ban Non Wat, there was a gradual positive shift $\left(0.8-0.9 \%\right.$ ) of $\delta^{13} \mathrm{C}$ starting from $-13.44 \%$ during its Bronze Age II (1000-900 B.C.) to Iron Age I. King and colleagues (2013) attribute the less negative $\delta^{13} \mathrm{C}$ values of Ban Non Wat Iron Age individuals to a dietary shift from a rice-based diet during the Bronze Age to the incorporation of other foodstuffs $\left(\mathrm{C}_{4}\right.$ crops or meat) as dietary supplements as northeast Thailand became drier during the Bronze-Iron Age transition. The drying event in this region has been documented by geomorphology (McGrath and Boyd 2001), $\delta^{18} \mathrm{O}$ values from stalagmites (Maher 2008; Wang et al. 2005) and foraminifera (Lückge et al. 2001), $\delta^{18} \mathrm{O}$ values from Ban Non Wat human tooth enamel (King et al. 2013), and, most recently, combined palaeoenvironmental and archaeological contexts (Wohlfarth et al. 2016). Since Promtin Tai was mainly an Iron Age occupation, Bronze Age samples were not available to verify if the drying event was also evident in central Thailand. However, from Iron Age I to II (200 B.C.-A.D. 200), there was a slight decrease of $\delta^{13} \mathrm{C}(0.25 \%)$ in Ban Non Wat, accompanied by an increase of $\delta^{18} \mathrm{O}$ (King et al. 2013). In Promtin Tai, a reverse trend was observed, where a slight increase of $\delta^{13} \mathrm{C}(0.25 \%$ o) and a decrease of $\delta^{18} \mathrm{O}(0.82 \%$ ) occurred between the Earlier and Later periods, although the differences were not statistically significant (Table 2, Fig. 2). Since an inverse relationship is expected between the amount of precipitation and $\delta^{18} \mathrm{O}$ values in tropical areas (Dansgaard 1964), the drying event is not evident in Promtin Tai isotopes (Table 2, Fig. 2). There is a lack of significant difference of mean $\delta^{18} \mathrm{O}$ between Earlier 
and Later Iron Age Promtin Tai. While we eagerly await more palaeoenvironmental studies focusing on central Thailand, the differences in geological, hydrological, and ecological characteristics between central and northeast Thailand provide the most probable explanations for the isotopic disparities (Higham and Thosarat 1998, 2012).

When the data are evaluated by sex, males are seen to have a slightly more positive mean $\delta^{13} \mathrm{C}$ and smaller variation than females, while females have a more positive mean $\delta^{18} \mathrm{O}$ with greater variation than males (Table 2). However, there is no statistically significant difference in mean values between sexes for either $\delta^{13} \mathrm{C}$ or $\delta^{18} \mathrm{O}$ (Mann-Whitney $U$ test, $p=0.23$ and 0.63 , respectively). This suggests that there was no dietary difference during people's early childhood to early adolescence, regardless of sex. All the people who were buried at Promtin Tai were likely to have consumed foodstuffs from sources with similar isotopic characteristics.

Tooth enamel mineralized during the first few years of life often captures isotope signals associated with breastfeeding. Isotopically, breast-fed infants are one trophic level above the mothers as the former is the consumer of the latter's tissue (Katzenberg 2008). It could be expected that teeth mineralized during exclusive breast milk consumption would have slightly higher $\delta^{13} \mathrm{C}$ values than those mineralized after the onset and/or completion of weaning (Dupras and Tocheri 2007; Fuller et al. 2006; Wright and Schwarcz 1998). For $\delta^{18} \mathrm{O}$, breast milk is enriched in the heavier stable isotope $\left({ }^{18} \mathrm{O}\right)$ than body water in a mother's system. Thus, tooth enamel mineralized while consuming breast milk should carry a higher $\delta^{18} \mathrm{O}$ value than those mineralized thereafter (Wright and Schwarcz 1998). For Promtin Tai, two of the five teeth mineralized during breastfeeding (both permanent first molars) do show less negative $\delta^{18} \mathrm{O}$ values, while the other three fall among the values of other later forming teeth. The trophic level effect on $\delta^{13} \mathrm{C}, 1 \%$ increase per trophic level (DeNiro and Epstein 1978), is also not consistently displayed as the $\delta^{13} \mathrm{C}$ values of tooth enamel mineralized during at least a portion of breastfeeding (i.e., deciduous first molar, permanent first molar, and permanent second premolar) fall within the range of other tooth types (Hillson 1996). The lack of a pattern related to breastfeeding may be caused by the mothers' broad-spectrum diet, as suckling children's isotopic profiles would build upon those of their mothers.

To explore how, or whether, Promtin Tai people responded to the inferred landscape change during its occupation, the data are evaluated by time period (Table 2 , Fig. 2). As shown in Table 2, the $\delta^{18} \mathrm{O}$ values of the Earlier Iron Age people are more positive than their Later period counterparts (Mann-Whitney $U$ test, $p=0.06$ ). The $\delta{ }^{13} \mathrm{C}$ values seem to present a visual pattern where data from Later Iron Age burials shift positively on the $\delta^{13} \mathrm{C}$ spectrum. However, this pattern is not statistically significant $(p=0.48)$. With the potential bias of small and uneven sample sizes in mind, if the three Later Iron Age data points do indeed represent an actual shift of diet from the Earlier period, the increasing input of freshwater resources may be a contributing factor. As mentioned earlier, freshwater fauna inhibiting shallower waters tend to be more enriched in $\delta^{13} \mathrm{C}$ (Hecky and Hesslein 1995; Katzenberg and Weber 1999), possibly due to their carbon sources being organic carbon from terrestrial runoff and decomposed organisms in nearshore water. In Promtin Tai, Lertcharnrit (2014) suggests that aquatic fauna may have been collected from nearby ponds, rice fields, and rivers. These water bodies tend to be quite shallow, elevating the $\delta^{13} \mathrm{C}$ values of the consumers of these aquatic resources. If this is the case, it would support the hypothesis that Promtin Tai people mitigated the declining availability of wild terrestrial fauna 
over time by increasing consumption of freshwater foods. Future analyses on the temporal distribution of freshwater bivalves, fish, and snails would verify this explanation.

Other factors may contribute to the slight positive shift on the $\delta^{13} \mathrm{C}$ spectrum observed here. First, as heightened demand for firewood led to further deforestation, the canopy effect needs to be considered. The term describes the decreasing $\delta^{13} \mathrm{C}$ gradient of leaves from the top of the canopy to the understory in a closed forest. In addition to blocking sunlight, a dense canopy prevents rapid mixing of atmospheric $\mathrm{CO}_{2}$ with biogenic $\mathrm{CO}_{2}$ from plant respiration and decomposed organic matter. The more negative $\delta^{13} \mathrm{C}$ value of plant tissues toward the forest floor is a combined result of low light intensity (which hinders the efficiency of photosynthesis) and ${ }^{13} \mathrm{C}$-depleted biogenic $\mathrm{CO}_{2}$ (Ambrose 1993; van der Merwe and Medina 1991). As one moves from a closed to an open canopy forest or an open field, irradiance and the mixture of biogenic and atmospheric $\mathrm{CO}_{2}$ become more aligned with natural baselines, thus eliminating the $\delta^{13} \mathrm{C}$ disparity among leaves from different canopy levels. The canopy effect is well-documented in a wide range of ecosystems (Ambrose 1993; Heaton 1999; Medina and Minchin 1980; van der Merwe and Medina 1991) and has been used to assess $\delta^{13} \mathrm{C}$ variation with respect to human foraging behavior in closed versus open canopy settings (Krigbaum 2001, 2003; Reitsema et al. 2013). While modern land use in this area focuses on rice agriculture and cash crop cultivation (Laosuksri and Qi 2014; personal observation 2007-2011), the central Thai region in prehistory was likely dominated by dipterocarps as part of the subtropical forest (Higham and Thosarat 2012). The slight shift of $\delta^{13} \mathrm{C}$ value during the Later Iron Age at Promtin Tai could reflect a shift from incorporating food items sourced more from closed-canopy forests to foraging at the edges of forests or open fields. This echoes the previously discussed premise that landscape alterations, including small-scale forest clearing, may have taken place during the Later Iron Age to accommodate population and site expansion or a higher demand for firewood to fuel intensified metal-working, or both.

The other possibility contributing to the small temporal shift of $\delta^{13} \mathrm{C}$ is the increasing consumption of domestic animals to offset diminishing wild terrestrial fauna. While not yet substantiated by nuanced faunal data for Promtin Tai, domestic cattle, pigs, dogs, and possibly chickens were almost certainly available to its people, given the long history of animal domestication in central Thailand and nearby regions. An increased amount of animal protein in the diet would slightly enrich $\delta^{13} \mathrm{C}$ (DeNiro and Epstein 1978). The effect of animal protein in diet could have been better gauged by measuring $\delta^{15} \mathrm{~N}$ from bone collagen. Unfortunately, attempts to extract viable collagen from Promtin Tai human bone samples have not been successful.

Subsistence strategies responding to landscape changes need not be limited to changing foraging/cultivation locales and/or resorting to domestic animals. Noting the disparity between the large amount of slag and the rarity of copper ingots, Lertcharnrit (2014) argues that metallurgical activities at Promtin Tai were conducted for exchange purposes. Items that may have been traded in to the site include personal ornaments made of a high tin-bronze alloy, fine-grained pottery vessels, stone bracelets, and pottery with special typological designs (Lertcharnrit 2006). In addition, glass beads from Promtin Tai are highly diverse in their morphology, chemical composition, and manufacturing technique (Carter 2013), all of which points to the likelihood that the Promtin Tai people had access to and 
participated in exchange networks starting in the earlier Iron Age. These networks continued well into the historical period, connecting Promtin Tai and central Thailand in general via river systems to the Gulf of Thailand, India, coastal Cambodia, southern Vietnam, and the Thai/Malay peninsula (Carter 2013; Glover and Bellina 2011). Lertcharnrit (2014) observes that copper ingots similar to those manufactured at Promtin Tai were distributed to the central highlands as far as $70 \mathrm{~km}$ east of the site. The existence of well-established exchange networks implies the possibility that food items were also involved. Items such as grains and dried meat or fish could easily be traded in to supplement the people's diet. With the potential impact of increasing forest clearing in the Later period driving some wild terrestrial animals further from the occupation area, intensified exchange involving animal proteins is a reasonable mitigating strategy.

\section{CONCLUSION}

Overall, human tooth enamel apatite data and evidence from the archaeological context indicate that rice, other $\mathrm{C}_{3}$ plants, freshwater fauna and flora, and $\mathrm{C}_{3^{-}}$ consuming fauna were likely the main dietary sources for the Iron Age Promtin Tai people, supplemented by traded food items such as millet and animal proteins. This broad-spectrum diet, anchored by $\mathrm{C}_{3}$ foods, is a classic subtropical and tropical regime in keeping with various prehistoric sites in Southeast Asia, including pre-Neolithic and Neolithic Borneo (Krigbaum 2001, 2003, 2005), late Neolithic and the equivalent of an early Metal Age in coastal central Thailand (Bentley et al. 2007), and pre-Metal and Metal Age northeast Thailand (King et al. 2013; King 2006; King and Norr 2006). Small-scale forest clearing to make way for site expansion and intensified communitybased metallurgy during the Later period at Promtin Tai may have hindered the accessibility of some wild terrestrial animals. The people responded to this by gathering foodstuffs from more open canopy areas and continuing and maybe slightly intensifying the collection of freshwater sources. The abundance of natural resources available to the Promtin Tai people throughout site occupation and the established broad-spectrum dietary strategy probably eliminated the need to alter the diet drastically. Promtin Tai's active engagement in numerous far-reaching trade networks would offset the decreasing terrestrial animal protein sources by bringing in food items to supplement people's diet.

This study of human responses to landscape changes during prehistoric occupation of Promtin Tai highlights the multifaceted nature of human-landscape interaction with regard to foodways. Varied and flexible subsistence strategies can mitigate the risks of food shortages or an imbalanced diet. Despite its small size and inferior preservation, the wealth of inferences derivable from the Promtin Tai human skeletal remains and archaeological context demonstrate the significance of the small prehistoric communities that were ubiquitous in central Thailand and beyond. These sites were often connected by waterways. The evidence of shared or transmitted cultural contexts at these sites suggest that their inhabitants actively participated in exchange networks (Carter 2013; Eyre 2006; Higham and Thosarat 1998, 2012). Detailed investigation and integration of human behavioral variation from these small sites will continue to shed light on changing patterns of human-landscape interaction and the complex cultural history of prehistoric Thailand and Mainland Southeast Asia. 


\section{ACKNOWLEDGMENTS}

I am grateful to the Promtin Tai site director Thanik Lertcharnrit for inviting me to the 2007 field season and granting permission to continuously study skeletal remains excavated in the subsequent seasons. Faculty, staff, and students from Silpakorn University, field crew, and the Promtin Tai villagers offered valuable intellectual input, oral histories, translation, and logistic support. The Fine Arts Department and the National Research Council of Thailand granted permission to study and export the biological remains. John Krigbaum and Jason Curtis at the University of Florida facilitated the intellectual and analytical aspects of this study. This project was funded by the Henry Luce Foundation/American Council of Learned Societies Grant to Individuals in East and Southeast Asian Archaeology and Early History Dissertation Fellowship. I also thank the editors' and four anonymous reviewers' constructive comments that greatly improved this manuscript.

\section{NOTES}

1. The name of the site is transliterated variously as Phromthin Tai, Phrom Thin Tai, and Promthin Tai in the literature.

\section{REFERENCES CITED}

Ambrose, Stanley H.

1993 Isotopic analysis of paleodiets: Methodological and interpretive considerations, in Investigations of Ancient Human Tissue: Chemical Analyses in Anthropology: 59-130, ed. M. K. Sandford. Langhorne: Gordon and Breach.

Ambrose, Stanley H., Jane Buikstra, and Harold W. Krueger

2003 Status and gender differences in diet at Mound 72, Cahokia, revealed by isotopic analysis of bone. Journal of Anthropological Archaeology 22(3):217-226.

Ambrose, Stanley H., Brian M. Butler, Douglas B. Hanson, Rosalind L. Hunter-Anderson, and Harold W. KRuEger

1997 Stable isotopic analysis of human diet in the Marianas archipelago, Western Pacific. American Journal of Physical Anthropology 104(3):343-361.

Ambrose, Stanley H., and Lynette Norr

1993 Experimental evidence for the relationship of the carbon isotope ratios of whole diet and dietary protein to those of bone collagen and carbonate, in Prehistoric Human Bones: Archaeology at the Molecular Level: 1-37, ed. J. B. Lambert and G. Grupe. Berlin: SpringerVerlag.

Arnold, Jeanne E., and Lana S. Martin

2014 Botanical evidence of paleodietary and environmental change: Drought on the Channel Islands, California. American Antiquity 79(2):227-248.

Atahan, Pia, Kliti Grice, and John Dodson

2007 Agriculture and environmental change at Qingpu, Yangtze delta region, China: A biomarker, stable isotope and palynological approach. The Holocene 17(4):507-515.

Bellina, Bérénice, and IAn Glover

2004 The Archaeology of early contact with India and the Mediterranean world: From the fourth century BC to the fourth century AD, in Southeast Asia: From Prehistory to History: 66-87, ed. I. Glover and P. Bellwood. New York: RoutledgeCurzon.

Bentley, R. Alexander, Nancy Tayles, Charles Higham, Colin Macpherson, and Tim C. Atkinson

2007 Shifting gender relations at Khok Phanom Di, Thailand: Isotopic evidence from the skeletons. Current Anthropology 48(2):301-314.

Bourke, Patricia, Sally Brockwell, Patrick Faulkner, and Betty Meehan

2007 Climate variability in the mid to late Holocene Arnhem Land Region, North Australia: Archaeological archives of environmental and cultural change. Archaeology in Oceania 42(3):91-101. 
Boyd, William E., And Roger J. McGrath

2001 The geoarchaeology of the prehistoric ditched sites of the upper Mae Nam Mun Valley, NE Thailand, III: Late Holocene vegetation history. Palaeogeography Palaeoclimatology Palaeoecology 171(3-4):307-328.

Brodie, Jedediah F., and Warken Y. Brockelman

2009 Bed site selection of red muntjac (Muntiacus muntjak) and sambar (Rusa unicolor) in a tropical seasonal forest. Ecological Research 24(6):1251-1256.

Bryant, J. Daniel, Paul L. Koch, Philip N. Froelich, William J. Showers, and Bernard J. Genna 1996 A tale of two quarries: Biologic and taphonomic signatures in the oxygen isotope composition of tooth enamel phosphate from modern and Miocene equids. Palaios 11 (4):397-408.

Buikstra, Jane E., and Douglas H. Ubelaker

1994 Standards: For Data Collection from Human Skeletal Remains. Fayetteville: Arkansas Archaeological Survey.

Carter, Alison Kyra

2013 Trade, Exchange, and Sociopolitical Development in Iron Age (500 BC-AD 500) Mainland Southeast Asia: An Examination of Stone and Glass Beads from Cambodia and Thailand. Ph.D. diss. University of Wisconsin-Madison, Madison.

Chapin, F. S., G. Peterson, F. Berkes, T. V. Callaghan, P. Angelstam, M. Apps, C. Beier,

Y. Bergeron, A. S. Crepin, K. Danell, T. Elmqvist, C. Folke, B. Forbes, N. Fresco,

G. Juday, J. Niemela, A. Shvidenko, and G. Whiteman

2004 Resilience and vulnerability of northern regions to social and environmental change. AMBIO 33(6):344-349.

Coltrain, Joan Brenner, and Steven W. Leavitt

2002 Climate and diet in Fremont prehistory: Economic variability and abandonment of maize agriculture in the Great Salt Lake Basin. American Antiquity 67(3):453-485.

Coplen, Tyler B., Carol Kendall, and Jessica Hopple

1983 Comparison of stable isotope reference samples. Nature 302:236-238.

Craig, Harmon

1957 Isotopic standards for carbon and oxygen and correction factors for mass-spectrometric analysis of carbon dioxide. Geochimica et Cosmochimica Acta 12(1-2):133-149.

Cremaschi, Mauro, Roberto Ciarla, and Vincent C. Pigott

1992 Paleoenvironment and late prehistoric sites in the Lopburi region of Central Thailand, in Southeast Asian Archaeology 1990: 167-177, ed. I. Glover. Hull: Centre for South-East Asian Studies, University of Hull.

DANSGAARD, W

1964 Stable isotopes in precipitation Tellus 16(4):436-468.

DeNiro, Michael J.

1987 Stable isotopy and archaeology. American Scientist 75(2):182-191.

DeNiro, Michael J., and Samuel Epstein

1978 Influence of diet on the distribution of nitrogen isotopes in animals. Geochimica et Cosmochimica Acta 42(3):495-506.

Deppen, Jacob, And Robert A. CoOK

2014 Deer use in good times and in bad: A Fort Ancient case study from southwest Ohio. Environmental Archaeology 19(1):72-83.

Dupras, Tosha L., and Matthew W. Tocheri

2007 Reconstructing infant weaning histories at Roman period Kellis, Egypt using stable isotope analysis of dentition. American Journal of Physical Anthropology 134(1):63-74.

Ekblom, Anneli, Barbara Eichhorn, Paul Sinclair, Shaw Badenhorst, and Amelie Berger

2014 Land use history and resource utilisation from A.D. 400 to the present, at Chibuene, southern Mozambique. Vegetation History and Archaeobotany 23(1):15-32.

EMERy, KitTy F.

2008 A zooarchaeological test for dietary resource depression at the end of the Classic period in the Petexbatun, Guatemala. Human Ecology 36(5):617-634. 
Eyre, Chureekamol Onsuwan

2006 Prehistoric and Proto-Historic Communities in the Eastern Upper Chao Phraya River Valley, Thailand: Analysis of Site Chronology, Settlement Patterns, and Land Use. Ph.D. diss. University of Pennsylvania, Philadelphia.

Fraser, R. A., A. Bogaard, M. Schäfer, R. Arbogast, and T.H.E. Heatond

2013 Integrating botanical, faunal and human stable carbon and nitrogen isotope values to reconstruct land use and palaeodiet at LBK Vaihingen an der Enz, Baden-Württemberg. World Archaeology 45(3):492-517.

Fuller, B. T., J. L. Fuller, D. A. Harris, and R.E.M. Hedges

2006 Detection of breastfeeding and weaning in modern human infants with carbon and nitrogen stable isotope ratios. American Journal of Physical Anthropology 129(2):279-293.

Glover, IAN

1980 Ban Don Ta Phet and its relevance to problems in the pre- and protohistory of Thailand. Bulletin of the Indo-Pacific Prehistory Association 2:16-30.

1983 Excavations at Ban Don Ta Phet, Kanchanaburi Province, Thailand, 1980-1. South-East Asian Studies Newsletter 10:1-3.

1990 Ban Don Ta Phet: The 1984-1985 excavation, in Southeast Asian Archaeology 1986: 139-184, ed. I. Glover and E. Glover. London: Institute of Archaeology, University College London.

Glover, Ian C., and Bérénice Bellina

2011 Ban Don Ta Phet and Khao Sam Kaeo: The earliest Indian contacts re-assessed, in Early Interactions between South and Southeast Asia: Reflections on Cross-Cultural Exchange: 17-46, ed. P.-Y. Manguin, A. Mani, and G. Wade. Singapore: ISEAS-Yusof Ishak Institute.

Hanley, Thomas A.

1996 Potential role of deer (Cervidae) as ecological indicators of forest management. Forest Ecology and Management 88(1):199-204.

Hanson, Sydney, and Jade d’Alpoim Guedes

2017 Millets and rice on the move. Unpublished paper presented at the 82nd Annual Meeting of the Society for American Archaeology, Vancouver, Canada, 29 March-2 April 2017.

Heaton, Tim H. E.

1999 Spatial, species, and temporal variations in the ${ }^{13} \mathrm{C} /{ }^{12} \mathrm{C}$ ratios of $\mathrm{C}_{3}$ plants: Implications for palaeodiet studies. Journal of Archaeological Science 26(6):637-649.

Hecky, R. E., and R. H. Hesslein

1995 Contributions of benthic algae to lake food webs as revealed by stable isotope analysis. Journal of the North American Benthological Society 14(4):631-653.

Higham, Charles

1975 Aspects of economy and ritual in prehistoric Northeast Thailand. Journal of Archaeological Science 2(4):245-288.

1996 The Bronze Age of Southeast Asia. Cambridge: Cambridge University Press.

2002 Early Cultures of Mainland Southeast Asia. Bangkok: River Books.

2004 Mainland Southeast Asia from the Neolithic to the Iron Age, in Southeast Asia: From Prehistory to History: 41-67, ed. I. Glover and P. Bellwood. London: RoutledgeCurzon.

Higham, Charles, and Thomas Higham

2009 A new chronological framework for prehistoric Southeast Asia, based on a Bayesian model from Ban Non Wat. Antiquity 83(319):125-144.

Higham, Charles, and Rachanie Thosarat

1994 Khok Phanom Di: Prehistoric Adaptation to the World's Richest Habitat. Fort Worth: Harcourt Brace.

1998 Prehistoric Thailand: From Early Settlements to Sukhothai. London: Thames and Hudson.

2012 Early Thailand: From Prehistory to Sukhothai. Bangkok: River Books.

Higham, C.F.W., AND B. F. LEACH

1971 An early centre of bovine husbandry in Southeast Asia. Science 172(3978):54-56.

HiLlson, Simon

1996 Dental Anthropology. New York: Cambridge University Press.

HOEFs, JOCHEN

2009 Stable Isotope Geochemisty, $6^{\text {th }}$ ed. Berlin: Springer-Verlag. 
Ilyas, O., AND J. A. KHAN

2003 Food habits of barking deer (Muntiacus muntjak) and goral (Naemorhedus goral) in Binsar Wildlife Sanctuary, India. Mammalia 67(4):521-531.

IndRawoOth, Phasook

2004 The archaeology of the early Buddhist kingdoms of Thailand, in Southeast Asia: From Prehistory to History: 120-148, ed. P. Bellwood and I. Glover. New York: RoutledgeCurzon.

Katzenberg, M. Anne

2008 Stable isotope analysis: A tool for studying past diet, demography, and life history, in Biological Anthropology of the Human Skeleton, $2^{\text {nd }}$ ed.: 413-441, ed. M. A. Katzenberg and S. R. Saunders. Hoboken: John Wiley \& Sons.

Katzenberg, M. Anne, And Andrzej Weber

1999 Stable isotope ecology and palaeodiet in the Lake Baikal region of Siberia. Journal of Archaeological Science 26(6):651-659.

KEALHOFER, LisA

1997 Evidence for cultural impact on the environment during the Holocene: Two phytolith sequences from the Lopburi region, central Thailand, in South-East Asian Archaeology 1992: 9-27, ed. R. Ciarla and F. Rispoli. Rome: Instituto Italiano per l'Africa e l'Oriente.

2002 Changing perceptions of risk: The development of agro-ecosystems in Southeast Asia. American Anthropologist 104(1):178-194.

Kealhofer, Lisa, and Peter Grave

2008 Land use, political complexity, and urbanism in mainland Southeast Asia. American Antiquity 73 (2):200-225.

KiJNGAM, A.

2011 The mammalian fauna, in The Origins of the Civilization of Angkor, vol. 4, The Excavation of Ban Non Wat, part 2: The Neolithic Occupation: 189-197, ed. C.F.W. Higham and A. Kijngam. Bangkok: Thai Fine Arts Department.

King, Charlotte L., R. Alexander Bentley, Nancy Tayles, Una Strand ViĐarsdóttir, Geoff Nowell, and Colin G. Macpherson

2013 Moving peoples, changing diets: Isotopic differences highlight migration and subsistence changes in the Upper Mun River Valley, Thailand. Journal of Archaeological Science 40 (4):1681-1688.

King, Christopher A.

2006 Paleodietary Change among Pre-State Metal Age Societies in Northeast Thailand: A Stable Isotope Approach. Ph.D. diss. University of Hawai'i at Mānoa, Honolulu.

King, Christopher A., And Lynette Norr

2006 Palaeodietary change among pre-state metal age societies in northeast Thailand: A study using bone stable isotopes, in Bioarchaeology of Southeast Asia: 241-262, ed. M. Oxenham and N. Tayles. Cambridge: Cambridge University Press.

Knudson, Kelly J., and Christina Torres-RoufF

2009 Investigating cultural heterogeneity in San Pedro de Atacama, northern Chile, through biogeochemistry and bioarchaeology. American Journal of Physical Anthropology 138(4): 473-485.

KrigBaum, JOHN

2001 Human Paleodiet in Tropical Southeast Asia: Isotopic Evidence from Niah Cave and Gua Cha. Ph.D. diss. New York University, New York.

2003 Neolithic subsistence patterns in northern Borneo reconstructed with stable carbon isotopes of enamel. Journal of Anthropological Archaeology 22(3):292-304.

2005 Reconstructing human subsistence in the West Mouth (Niah Cave, Sarawak) burial series using stable isotopes of carbon. Asian Perspectives 44(1):73-89.

Krueger, Harold W., and Charles H. Sullivan

1984 Models for carbon isotope fractionation between diet and bone, in Stable Isotopes in Nutrition: 205-220, ed. J. R. Turnlund and P. E. Johnson. Washington, D.C.: American Chemical Society.

LaOSUKSri, Walaiporn, AND GUBo Qi

2014 Reforestation in limestone forest in central Thailand: A case of Bann Lam Nam Kaew community forestry in Lopburi Province. Civil and Environmental Research 6(3):59-66. 
LeE-Thorp, Julia A.

1989 Stable Carbon Isotopes in Deep Time: The Diets of Fossil Fauna and Hominids. Ph.D. diss. University of Cape Town, Cape Town.

Lee-Thorp, Julia A., Judith C. Sealy, and Nikolaas J. van der Merwe

1989 Stable carbon isotope ratio differences between bone-collagen and bone apatite, and their relationship to diet. Journal of Archaeological Science 16(6):585-599.

Lee-Thorp, Julia A., and Nikolaas J. van der Merwe

1991 Aspects of the chemistry of modern and fossil biological apatites. Journal of Archaeological Science 18(3):343-354.

LERTCHARNRIT, THANIK

2006 The moated site of Promtin Tai and the transition from late prehistory to early history in central Thailand, in Uncovering Southeast Asia's Past: Selected Papers from the $10^{\text {th }}$ International Conference of the European Association of Southeast Asian Archaeologists: 258-265, ed. E. A. Bacus, I. C. Glover, and V. C. Pigott. Singapore: National University of Singapore Press.

2014 Phromthin Tai: An archaeological perspective on its societal transition, in Before Siam: Essays in Art and Archaeology: 119-131, ed. N. Revire and S. A. Murphy. Bangkok: River Books.

Lückge, A., H. Doose-Rolinski, A. A. Khan, H. Schulz, and U. von Rad

2001 Monsoonal variability in the northeastern Arabian Sea during the past 5000 years: Geochemical evidence from laminated sediments. Palaeogeography Palaeoclimatology Palaeoecology 167(3-4):273-286.

MAHER, B. A.

2008 Holocene variability of the East Asian summer monsoon from Chinese cave records: A reassessment. Holocene 18(6):861-866.

McGrath, R. J., AND W. E. Boyd

2001 The chronology of the Iron Age 'moats' of northeast Thailand. Antiquity 75(288):349-360.

Medina, E., AND P. Minchin

1980 Stratification of $\delta^{13} \mathrm{C}$ values of levels in Amazonian rain forests. Oecologia 45(3):377-378.

Mudar, Karen M.

1985 Bearded pigs and beardless men: Predator-prey relationships between pigs and Agta in northeastern Luzon, in The Agta of Northeastern Luzon: Recent Studies: 69-84, ed. P. B. Griffin and A. Estioko-Griffin. Cebu City, Philippines: University of San Carlos.

Mudar, Karen M., and Vincent C. Pigott

2003 Subsistence changes and community-based craft production in prehistoric central Thailand, in Fishbones and Glittering Emblems: Southeast Asian Archaeology 2002: 149-161, ed. A. Karlstrom and A. Kallen. Stockholm: Museum of Far Eastern Antiquities, Ostasiatiska Museet.

Natapintu, Surapol

1988 Current research on ancient copper-base metallurgy in Thailand, in Prehistoric Studies: The Stone and Metal Ages in Thailand: 107-124, ed. P. Charoenwongsa and B. Bronson. Bangkok: Thai Antiquity Working Group.

O’Leary, Marion H.

1981 Carbon isotope fractionation in plants. Phytochemistry 20(4):553-567.

1988 Carbon isotopes in photosynthesis. BioScience 38(5):328-336.

O’Reilly, Dougald J. W.

2001 From the Bronze Age to the Iron Age in Thailand: Applying the heterarchical approach. Asian Perspectives 39(1-2):1-19.

2003 Further evidence of heterarchy in Bronze Age Thailand. Current Anthropology 44 (2):300-306.

Pigott, Vincent C., Andrew D. Weiss, and Surapol Natapintu

1997 The archaeology of copper production: Excavations in the Khao Wong Prachan Valley, central Thailand, in South-east Asian Archaeology 1992: 119-157, ed. R. Ciarla and F. Rispoli. Rome: Istituto Italiano per l'Africa e l'Oriente.

Piper, PhiLip J.

2017 The origins and arrival of the earliest domestic animals in Mainland and Island Southeast Asia: A developing story of complexity, in New Perspectives in Southeast Asian and Pacific Prehistory: 251-273, ed. P. J. Piper, H. Matsumura, and D. Bulbeck. Canberra: Australian National University Press. 
Pryce, Thomas Oliver

2009 Prehistoric Copper Production and Technological Reproduction in the Khao Wong Prachan Valley of Central Thailand. Ph.D. Dissertation. University College London, London.

Reitsema, L. J., T. Kozlowski, and D. Makowiecki

2013 Human-environment interactions in medieval Poland: A perspective from the analysis of faunal stable isotope ratios. Journal of Archaeological Science 40(10):3636-3646.

Richerson, Peter J., Robert Boyd, and Robert Bettinger

2001 Was agriculture impossible during the Pleistocene but mandatory during the Holocene? A climate change hypothesis. American Antiquity 66(3):387-411.

Rispoli, Fiorella, Roberto Ciarla, and Vincent C. Pigott

2013 Establishing the prehistoric cultural sequence for the Lopburi region, central Thailand. Journal of World Prehistory 26(2):101-171.

Robiins Schug, Gwen

2011 Bioarchaeology and Climate Change: A View from South Asian Prehistory. Gainesville: University of Florida Press.

Schoeninger, Margaret J.

1985 Trophic level effects on ${ }^{15} \mathrm{~N} /{ }^{14} \mathrm{~N}$ and ${ }^{13} \mathrm{C} /{ }^{12} \mathrm{C}$ ratios in bone collagen and strontium levels in bone mineral. Journal of Human Evolution 14(5):515-525.

Schoeninger, Margaret J., K. Hallin, H. Reeser, John W. Valley, and John Fournelle

2003 Isotopic alteration of mammalian tooth enamel. International Journal of Osteoarchaeology 13(1-2):11-19.

Schoeninger, Margaret J., Katherine M. Moore, Matthew L. Murray, and John D. Kingston 1989 Detection of bone preservation in archaeological and fossil samples. Applied Geochemistry 4(3):281-292.

Tieszen, Larry L., And Tim Fagre

1993 Carbon isotopic variability in modern and archaeological maize. Journal of Archaeological Science 20(1):25-40.

Turner, Bethany L., and George J. Armelagos

2012 Diet, residential origin, and pathology at Machu Picchu, Peru. American Journal of Physical Anthropology 149(1):71-83.

Tyкот, Robert H.

2006 Isotope analysis and the histories of maize, in Histories of Maize: Multidisciplinary Approaches to the Prehistory, Biogeography, Domestication, and Evolution of Maize: 131-142, ed. J. E. Staller, R. H. Tykot, and B. F. Benz. New York: Academic Press.

Tykot, Robert H., F. Falabella, M. T. Planella, E. Aspillaga, L. Sanhueza, and C. Becker

2009 Stable isotopes and archaeology in central Chile: Methodological insights and interpretative problems for dietary reconstruction. International Journal of Osteoarchaeology 19(2):156-170.

van der Merwe, Nikolaas J., and Ernesto Medina

1991 The canopy effect, carbon isotope ratios and foodwebs in Amazonia. Journal of Archaeological Science 18(3):249-259.

Walker, Phillip L.

1989 Cranial injuries as evidence of violence in prehistoric southern-California. American Journal of Physical Anthropology 80(3):313-323.

Wang, Yang, and Thure E. Cerling

1994 A model of fossil tooth and bone diagenesis: Implications for paleodiet reconstruction from stable isotopes. Palaeogeography Palaeoclimatology Palaeoecology 107(3-4):281-289.

Wang, Yongjin, Hai Cheng, R. Lawrence Edwards, Yaoqi He, Xinggong Kong, Zhisheng An, Jiangying Wu, Megan J. Kelly, Carolyn A. Dykoski, and Xiangdong Li

2005 The Holocene Asian monsoon: Links to solar changes and North Atlantic climate. Science 308 (5723):854-857.

Weber, Steve, Heather Lehman, Timothy Barela, Sean Hawks, and David Harriman

2010 Rice or millets: Early farming strategies in prehistoric central Thailand. Archaeological and Anthropological Sciences 2(2):79-88. 
White, Christine D., Paul F. Healy, and Henry P. Schwarcz

1993 Intensive agriculture, social status, and Maya diet at Pacbitun, Belize. Journal of Anthropological Research 49(4):347-375.

White, Joyce C.

2011 Emergence of cultural diversity in mainland Southeast Asia: A view from prehistory, in Dynamics of Human Diversity: The Case of Mainland Southeast Asia: 9-46, ed. N. J. Enfield. Pacific Linguistics 627. Canberra: Pacific Linguistics.

White, Joyce C., and Elizabeth G. Hamilton

2009 The transmission of early bronze technology to Thailand: New perspectives. Journal of World Prehistory 22(4):357-397.

White, Joyce C., and Vincent C. Pigott

1996 From community craft to regional specialization: Intensification of copper production in prestate Thailand, in Craft Specialization and Social Evolution: In Memory of V. Gordon Childe: 151-175, ed. B. Wailes. Philadelphia: The University Museum of Archaeology and Anthropology, University of Pennsylvania.

Wohlfarth, Barbara, Charles Higham, Kweku Afrifa Yamoah, Akkaneewut Chabangborn, Sakonvan Chawchai, and Rienk H. Smittenberg

2016 Human adaptation to mid- to late-Holocene climate change in Northeast Thailand. The Holocene 26(11):1-12.

Wright, Lori E., and Henry P. Schwarcz

1998 Stable carbon and oxygen isotopes in human tooth enamel: Identifying breastfeeding and weaning in prehistory. American Journal of Physical Anthropology 106(1):1-18.

Wright, Lori E., And Christine D. White

1996 Human biology in the Classic Maya collapse: Evidence from paleopathology and paleodiet. Journal of World Prehistory 10(2):147-198.

ZEDER, MELINDA A.

2008 Domestication and early agriculture in the Mediterranean Basin: Origins, diffusion, and impact. PNAS 105(3):11597-11604.

Zohary, Tamar, Jonathan Erez, Moshe Gophen, Ilana Berman-Frank, and Mariana Stiller

1994 Seasonality of stable carbon isotopes within the pelagic food web of Lake Kinneret. Limnology and Oceanography 39(5):1030-1043. 